\title{
ZASTOSOWANIE METODY RÓŻNIC SKOŃCZONYCH W DYNAMICE CIENKICH PLYT MOSTOWYCH PODDANYCH DZIALANIU OBCIĄŻEŃ RUCHOMYCH
}

\begin{abstract}
Praca przedstawia rozwiązanie zagadnienia drgań nietłumionych cienkiej prostokątnej płyty mostowej poddanej działaniu obciążenia nieinercyjnego poruszającego się ze stałą prędkością. Zastosowane zostały znane procedury numeryczne Metody Różnic Skończonych, mające na celu dyskretyzację przestrzenną obszaru płyty, a także algorytmy metody Newmarka przy dyskretyzacji czasu przejazdu obciążenia przez płytę. Podano formuły pozwalające zbudować i rozwiązać macierzowe równanie ruchu w tym budowę wektorów obciążeń dla przypadku ruchomej siły skupionej oraz ruchomego obciążenia rozłożonego. Praca uzupełniona jest przykładem numerycznym płyty mostowej podpartej 4 słupami obciążonej dwoma rodzajami obciążenia ruchomego.
\end{abstract}

Słowa kluczowe: Metoda Różnic Skończonych, obciążenia ruchome, płyta cienka, metoda Newmarka

\section{Wprowadzenie}

Zagadnienie drgań konstrukcji poddanych działaniu obciążeń ruchomych jest zarówno istotne jak i interesujące $\mathrm{z}$ teoretycznego punktu widzenia oraz częstego występowania $\mathrm{w}$ praktyce projektowej. W ciągu wielu lat problem ten był analizowany przez wielu autorów rozpatrujących różne typy konstrukcji, zarówno płaskich jak i przestrzennych, a także różne modele obciążeń ruchomych [1-7].

Niniejsza praca poświęcona jest cienkim prostokątnym płytom mostowym poddanym działaniu różnego rodzaju nieinercyjnych obciążeń ruchomych (ruchoma siłą skupiona oraz ruchome obciążenie równomiernie rozłożone). Zagadnienie zostało rozwiązane w sposób numeryczny przy zastosowaniu algorytmów Metody Różnic Skończonych przy dyskretyzacji przestrzennej obszaru płyty oraz metody Newmarka przy dyskretyzacji czasu przejazdu obciążenia po płycie.

${ }^{1}$ Autor do korespondencji / corresponding author: Filip Zakęś, Uniwersytet Przyrodniczy we Wrocławiu, Zakład Mechaniki i Wytrzymałości Materiałów, Pl. Grunwaldzki 24, 50-363 Wrocław; tel. 713205521; filip.zakes@up.wroc.pl. 


\section{Metoda Różnic Skończonych}

Rozpatrzmy cienką prostokątną płytę o wymiarach $B x L$ podpartą swobodnie na przeciwległych krawędziach wzdłuż wymiaru $B$ oraz nie posiadającą podparcia na krawędziach wzdłuż wymiaru $L$ (rys.1a). Drgania nietłumione takiej płyty poddanej działaniu obciążenia $p$ poruszającego się wzdłuż krawędzi $L$ ze stałą prędkością $v$ opisuje równanie:

$$
D\left[\frac{\partial^{4} w(x, y, t)}{\partial x^{4}}+2 \frac{\partial^{4} w(x, y, t)}{\partial x^{2} y^{2}}+\frac{\partial^{4} w(x, y, t)}{\partial x^{4}}\right]+\rho h \frac{\partial^{2} w(x, y, t)}{\partial t^{2}}=p(x, y, t)
$$

Gdzie $D=\frac{E h^{3}}{12\left(1-v^{2}\right)}$ oznacza sztywność giętną płyty, $h$ jej grubość, $\rho$ gęstość materiału, $E$ moduł Younga, a $v$ współczynnik Poissona. Funkcja obciążenia $p(x, y, t)$ przyjmuje postać $p(x, y, t)=P \delta(x-v t) \delta\left(y-y_{o}\right)$ w przypadku gdy płyta obciążona jest ruchomą skupioną siłą $P$ lub w przypadku ruchomego obciążenia $q$ równomiernie rozłożonego $p(x, y, t)=q H(v t-x) \delta\left(y-y_{o}\right)$. Symbolem $\delta$ oznaczono deltę Diraca, a $H$ oznacza funkcję Heaviside'a.

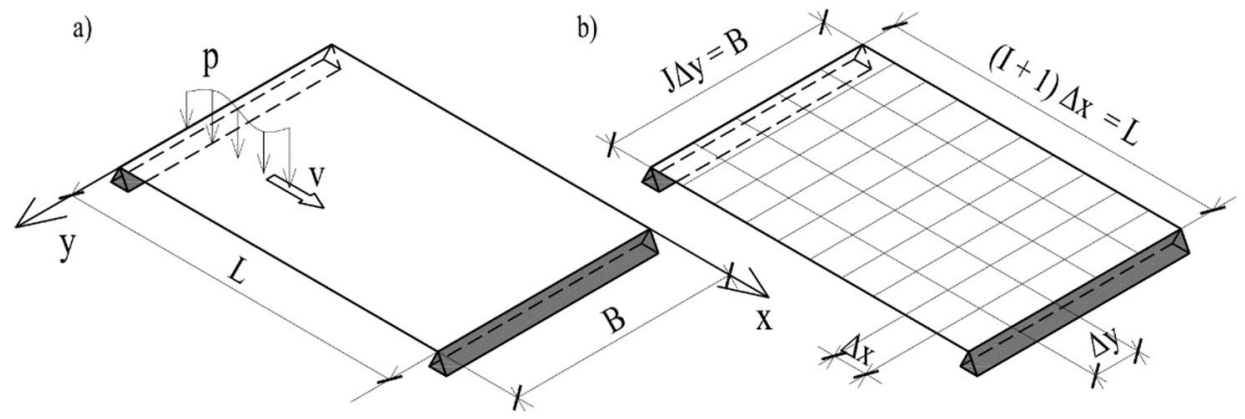

Rys. 1. Cienka płyta mostowa; a) model ciągły; b) model dyskretny

Fig. 1. A thin bridge plate; a) continuous model; b) discrete model

Stosując procedurę Metody Różnic Skończonych dzielimy obszar płyty liniami prostopadłymi do krawędzi $B$ i $L$ tworząc w ten sposób siatkę dyskretyzacyjną o wymiarach oczka $\Delta x \cdot \Delta y$ (rys. 1b). Punkty przecięcia linii tworzą węzły siatki w których wyznaczać będziemy ugięcia dynamiczne płyty $w_{i, j}=w\left(x_{i}, y_{j}, t\right)$ bazując na przyjętej formule różnicowej:

$$
\begin{aligned}
& D\left[\frac{\partial^{4} w(x, y, t)}{\partial x^{4}}+2 \frac{\partial^{4} w(x, y, t)}{\partial x^{2} y^{2}}+\frac{\partial^{4} w(x, y, t)}{\partial x^{4}}\right]= \\
& =\frac{D}{\lambda^{4}}\left[20 w_{i, j}-8\left(w_{i-1, j}+w_{i+1, j}+w_{i, j-1}+w_{i, j+2}\right)+2\left(w_{i-1, j-1}+w_{i-1, j+1}\right.\right. \\
& \left.\left.+\quad w_{i+1, j-1}+w_{i+1, j+1}\right)+\left(w_{i-2, j}+w_{i+2, j}+w_{i, j-2}+w_{i, j+2}\right)\right]
\end{aligned}
$$


gdzie $\lambda=\Delta x=\Delta y, i=1,2, \ldots, I, j=0,1, \ldots, J . \mathrm{W}$ ten sposób równanie różniczkowe (1) zastępujemy układem $I \cdot J$ równań algebraicznych postaci:

$$
\begin{aligned}
\frac{D}{\lambda^{4}}\left[20 w_{i, j}-8(\right. & \left.w_{i-1, j}+w_{i+1, j}+w_{i, j-1}+w_{i, j+2}\right) \\
& +2\left(w_{i-1, j-1}+w_{i-1, j+1}+w_{i+1, j-1}+w_{i+1, j+1}\right) \\
& \left.+\left(w_{i-2, j}+w_{i+2, j}+w_{i, j-2}+w_{i, j+2}\right)\right]+m_{i, j} \ddot{w}_{i, j}=p_{i, j}
\end{aligned}
$$

gdzie $\ddot{w}_{i, j}=\frac{\partial^{2} w\left(x_{i}, y_{j}, t\right)}{\partial t^{2}}$. Układ równań (3) można przedstawić w postaci macierzowej:

$$
\boldsymbol{M} \ddot{\bar{w}}(t)+\boldsymbol{K} \bar{w}(t)=\bar{p}(t)
$$

gdzie $\boldsymbol{K}$ jest macierzą sztywności, $\boldsymbol{M}=\operatorname{diag}\left\{m_{i, j}\right\}$ jest macierzą bezwładności $\left(m_{i, j}=\rho h\right.$ dla $j \neq 0 ; j \neq J ; \quad m_{i, j}=\frac{\rho h}{2}$ dla $\left.j=0 ; j=J\right)$, natomiast $\bar{p}(t)$ jest wektorem obciążenia.

\subsection{Warunki brzegowe}

Równania algebraiczne (3) należy zmodyfikować uwzględniając odpowiednie warunki brzegowe określające współczynniki występujące przy ugięciach odpowiednich węzłów siatki MRS [8]. Na rysunku 2 przedstawiono schematycznie wartości współczynników dla charakterystycznych punktów płyty mostowej o dwóch krawędziach swobodnie podpartych oraz dwóch krawędziach swobodnych. Dla wszystkich pozostałych węzłów obowiązują równania w postaci (2).

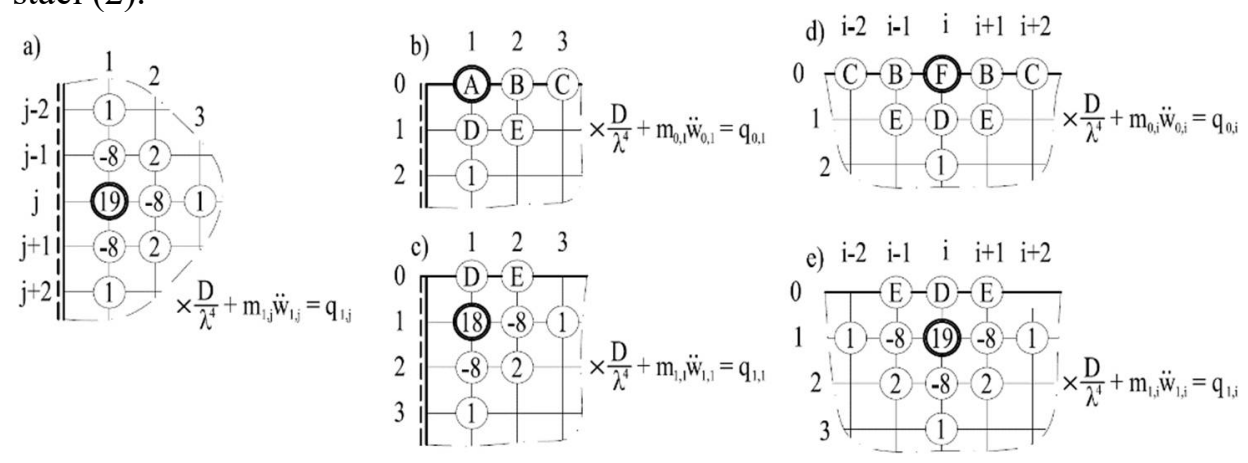

Rys. 2. Współczynniki przy ugięciach węzłów: a) węzeł w sąsiedztwie brzegu swobodnie podpartego; b) węzeł na krawędzi swobodnej w sąsiedztwie krawędzi swobodnie podpartej; c) węzeł w sąsiedztwie krawędzi swobodnie podpartej i swobodnej; d) węzeł na krawędzi swobodnej; e) węzeł w sąsiedztwie krawędzi swobodnej

Fig. 2. Node deflection coefficients: a) node adjacent to a pinned edge; b) node on a free edge adjacent to a pinned edge; c) node adjacent to a pinned-free corner; d) node on a free edge; e) node adjacent to a free edge 
Współczynniki $A, B, C, D, E, F$ widoczne na schematach $2 \mathrm{~b}-2 \mathrm{e}$ wynoszą odpowiednio:

$$
\begin{aligned}
& A=\frac{15-8 v-5 v^{2}}{2} ; \quad B=-2(2+v)(1-v) ; \quad C=\frac{1-v^{2}}{2} ; D=-2(3-v) ; \\
& E=2-v ; \quad F=8-4 v-3 v^{2}
\end{aligned}
$$

\subsection{Modele obciążeń ruchomych}

Wektor obciążenia $\bar{p}(t)$ występujący w równaniu (4) ma postać:

$$
\bar{p}(t)=\left[\begin{array}{c}
p_{1,0} \\
\vdots \\
p_{i, j} \\
\vdots \\
p_{I, J}
\end{array}\right] \quad p_{i, j}=p\left(x_{i}, y_{j}, t\right)
$$

Rozpatrywać będziemy przypadek ruchomej siły skupionej o stałej wartości $P$ oraz ruchomego obciążenia równomiernie rozłożonego $q$ poruszającego się wzdłuż linii $j$ (rys. 3).
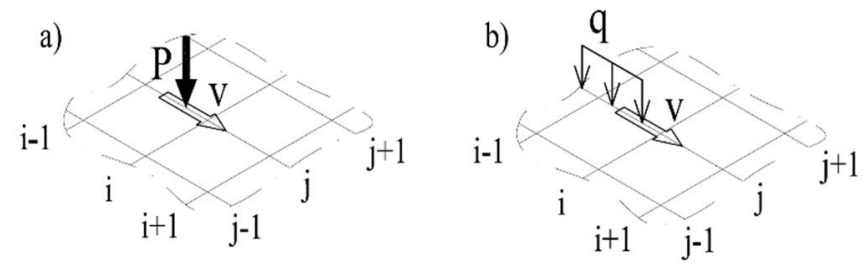

Rys. 3. Przypadki obciążenia ruchomego: a) ruchoma siła, b) ruchome obciążenie rozłożone Fig. 3. Cases of moving load: a) moving point force, b) moving distributed load

Wyrazy $p_{i, j}$ wektora (6) w przypadku ruchomej siły skupionej mają postać:

$$
\begin{aligned}
& p_{i-1, j}(t)=P \frac{t_{i}-t}{\lambda^{2} \Delta t_{i}} ; \quad p_{i, j}(t)=P \frac{t-t_{i-1}}{\lambda^{2} \Delta t_{i}} ; j \neq 0, j \neq J, \\
& p_{i-1, j}(t)=P \frac{t_{i}-t}{2 \lambda^{2} \Delta t_{i}} ; \quad p_{i, j}(t)=P \frac{t-t_{i-1}}{2 \lambda^{2} \Delta t_{i}} ; j=0, j=J, \\
& p_{r, s}(t)=0 \text { dla } r \neq i, r \neq i-1, \quad s \neq j
\end{aligned}
$$

natomiast w przypadku ruchomego obciążenia równomiernie rozłożonego:

$$
\begin{aligned}
& p_{i, j}(t)=q \frac{t-t_{i-1}}{\lambda \Delta t_{i}} ; j \neq 0, j \neq J, \\
& p_{i, j}(t)=q \frac{t-t_{i-1}}{2 \lambda \Delta t_{i}} ; j=0, j=J, \\
& \quad p_{r, s}(t)=q \text { dla } r<i, s=j ; \quad p_{r, s}(t)=0 \text { dla } r>i
\end{aligned}
$$

$\operatorname{gdzie} \Delta t_{i}=\frac{\lambda}{v}, t_{i}=i \Delta t_{i}$ 


\section{Całkowanie numeryczne równania ruchu}

Macierzowe równanie ruchu (4) może zostać rozwiązane numerycznie przy zastosowaniu metody Newmarka dla stałego przyśpieszenia [9]. Rozwiązanie polega na podziale czasu przejazdu obciążenia przez płytę na skończoną liczbę $N$ segmentów czasowych $\Delta t=L / N v$, a następnie wyznaczaniu wartości szukanych funkcji przemieszczeń oraz prędkości w kolejnych krokach całkowania w oparciu o znajomość wartości tych funkcji w kroku poprzednim. Formuły używane $\mathrm{w}$ tej metodzie służące wyznaczeniu wektorów przemieszczeń $\bar{w}\left(t_{n}\right)$ oraz prędkości $\dot{\bar{w}}\left(t_{n}\right)$ mają postać:

$$
\begin{aligned}
& \bar{w}\left(t_{n+1}\right)=\bar{w}\left(t_{n}\right)+\Delta t \dot{\bar{w}}\left(t_{n}\right)+\alpha(\Delta t)^{2} \ddot{\bar{w}}\left(t_{n}\right)+\beta(\Delta t)^{2} \ddot{\bar{w}}\left(t_{n+1}\right) \\
& \dot{\bar{w}}\left(t_{n+1}\right)=\dot{\bar{w}}\left(t_{n}\right)+\frac{1}{2} \Delta t\left[\ddot{\bar{w}}\left(t_{n}\right)+\ddot{\bar{w}}\left(t_{n+1}\right)\right]
\end{aligned}
$$

gdzie:

$$
\alpha=\frac{1}{2}-\beta ; \quad \beta=\frac{1}{4} ; \quad t_{n+1}=t_{n}+\Delta t ; \quad n=1,2, \ldots, N
$$

Wektor przyspieszeń nieznany w każdym kroku całkowania wyznaczamy z warunku:

$$
\widetilde{\boldsymbol{M}} \ddot{\bar{w}}\left(t_{n+1}\right)=\tilde{\bar{p}}\left(t_{n+1}\right)
$$

gdzie:

$$
\begin{aligned}
& \widetilde{\boldsymbol{M}}=\boldsymbol{M}+\beta(\Delta t)^{2} \boldsymbol{K} \\
& \tilde{\bar{p}}\left(t_{n+1}\right)=\bar{p}\left(t_{n+1}\right)-\boldsymbol{K}\left[\bar{w}\left(t_{n}\right)+\Delta t \dot{\bar{w}}\left(t_{n}\right)+\alpha(\Delta t)^{2} \ddot{\bar{w}}\left(t_{n}\right)\right]
\end{aligned}
$$

Równanie ruchu (4) rozwiązujemy przy założeniu zerowych warunków początkowych:

$$
\bar{w}\left(t_{0}=0\right)=\overline{0} ; \quad \dot{\bar{w}}\left(t_{0}=0\right)=\overline{0}
$$

\section{Przykład numeryczny}

Jako przykład obliczeniowy posłuży prostokątna płyta cienka o wymiarach $B \times L=10 \times 30 \mathrm{~m}$ i grubości $h=0,4 \mathrm{~m}$, podparta swobodnie na przeciwległych krótszych krawędziach oraz posiadająca 4 podpory punktowe w swoim obszarze. Płyta wykonana jest z materiału o gęstości równej $\rho=2400 \mathrm{~kg} / \mathrm{m}^{3}$, module Younga $E=30000 \mathrm{MPa}$ i współczynniku Poissona $v=0,2$. Model dyskretny Metody Różnic Skończonych zbudowano dzieląc obszar płyty siatką dyskretyzacyjną o wymiarach oczka $\Delta x=\Delta y=\lambda=1,0 \mathrm{~m}$. Płyta poddana jest działaniu siły skupionej o wartości $P=100 \mathrm{kN}$ (rys.4) oraz obciążenia liniowego 
o stałym natężeniu $q=50 \mathrm{kN} / \mathrm{m}$ (rys.5). Oba obciążenia poruszają się wzdłuż dłuższego boku płyty ze stałymi prędkościami $v=30 \mathrm{~m} / \mathrm{s}$ oraz $v=60 \mathrm{~m} / \mathrm{s}$. $\mathrm{W}$ dalszych obliczeniach analizowano drgania punktu „A" o współrzędnych $x_{A}=15 \mathrm{~m} ; y_{A}=5 \mathrm{~m}$ jak również deformację całej powierzchni płyty. Całkowanie numeryczne równania ruchu przeprowadzono dzieląc czas przejazdu obciążenia po płycie na $N=150$ równych odcinków czasowych. Wyniki obliczeń przedstawiono na rysunkach 6-9. Dla porównania podano również linie wpływu ugięcia statycznego płyty od siły skupionej $P$ oraz obciążenia rozłożonego $q$.

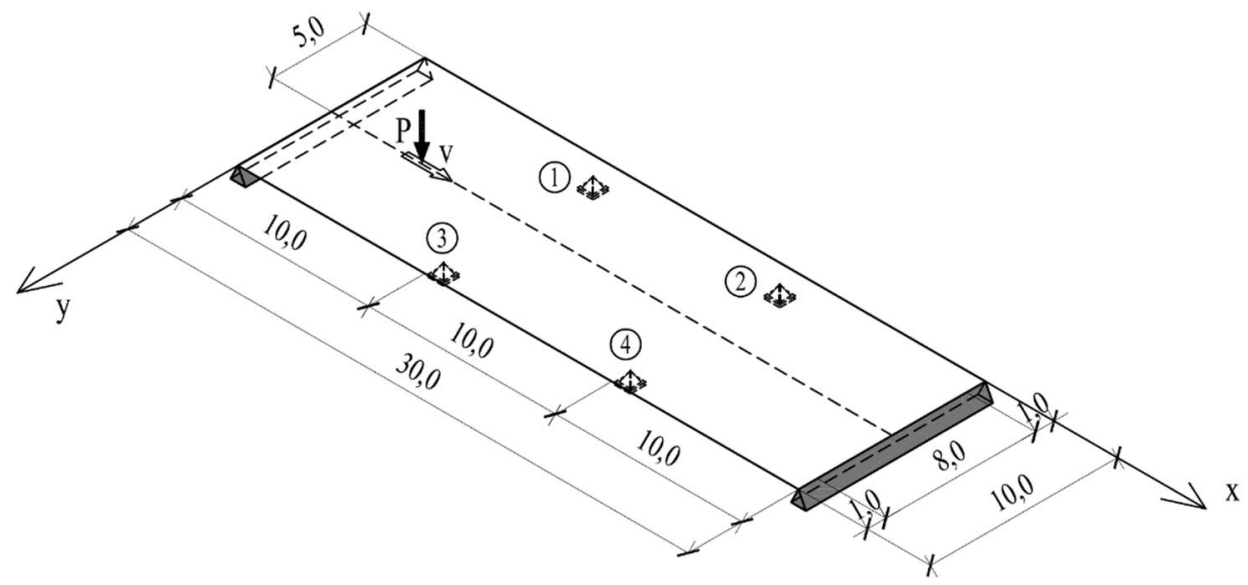

Rys. 4. Cienka płyta mostowa z 4 podporami punktowymi obciążona ruchomą siłą skupioną

Fig. 4. A thin bridge plate with 4 point supports subjected to a moving concentrated force

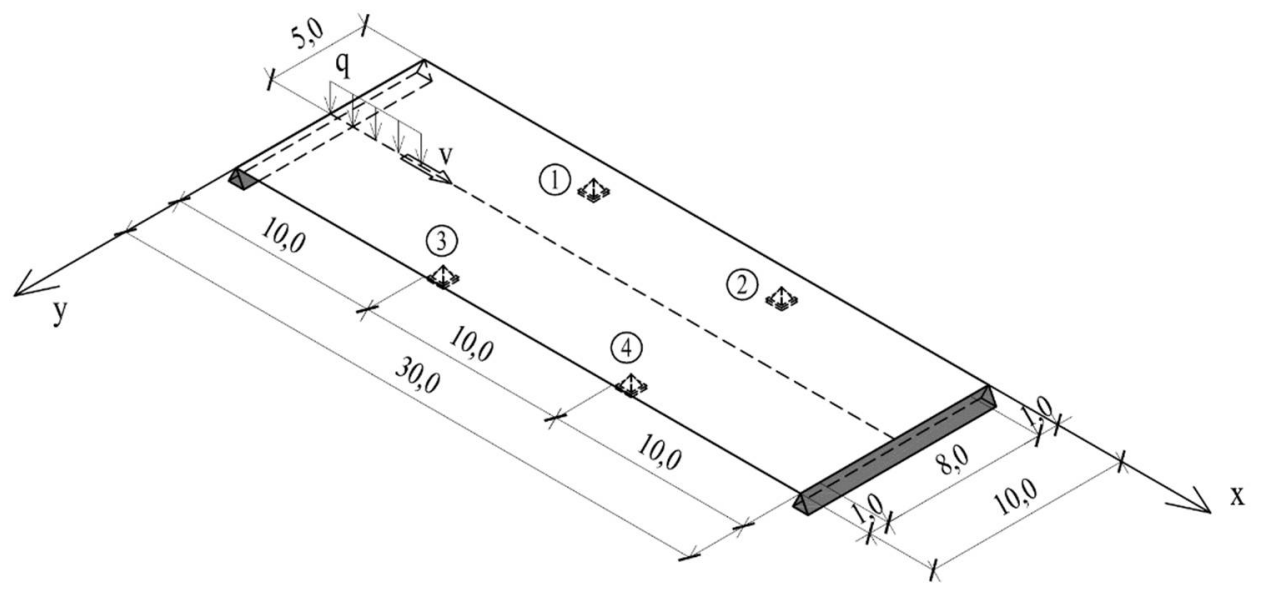

Rys. 5. Cienka płyta mostowa z 4 podporami punktowymi obciążona ruchomym obciążeniem rozłożonym

Fig. 5. A thin bridge plate with 4 point supports subjected to a moving distributed load 


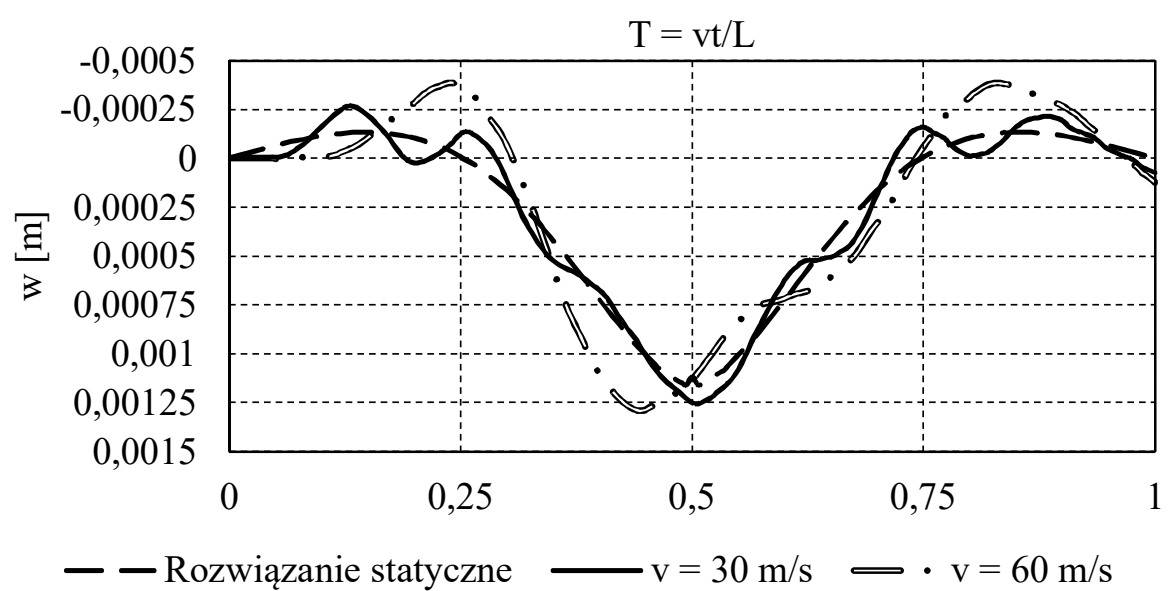

Rys. 6. Ugięcie dynamiczne punktu „A” wywołane ruchomą siłą skupioną siłą skupioną

Fig. 6. Dynamic deflection of point "A" resulting from the moving concentrated force

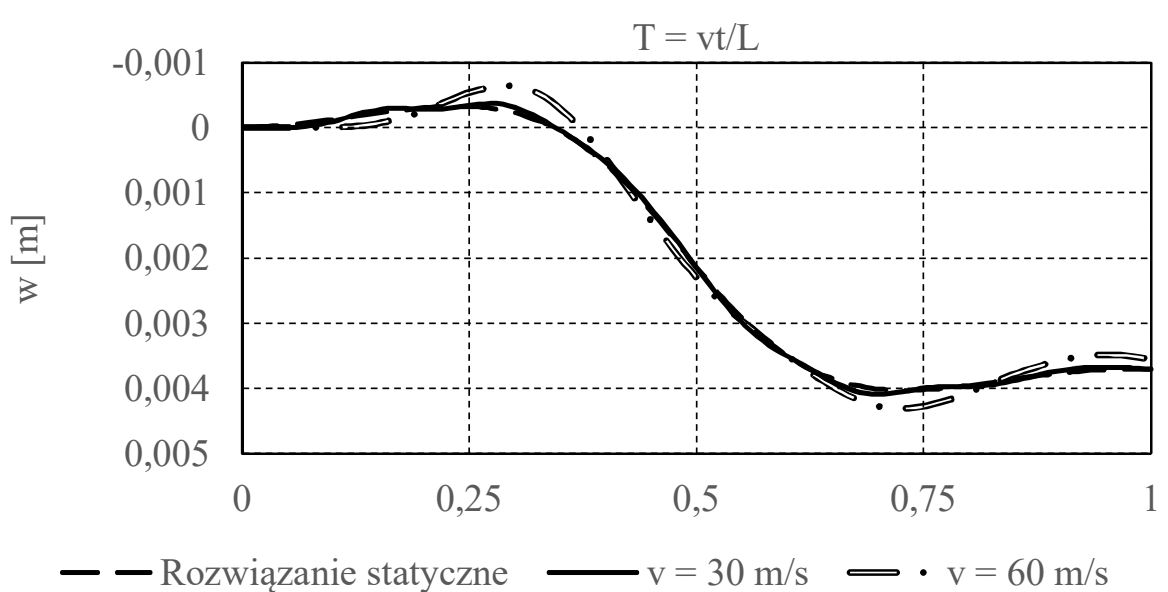

Rys. 7. Ugięcie dynamiczne punktu „A” wywołane ruchomym obciążeniem rozłożonym

Fig. 7. Dynamic deflection of point " $A$ " resulting from the moving distributed load 


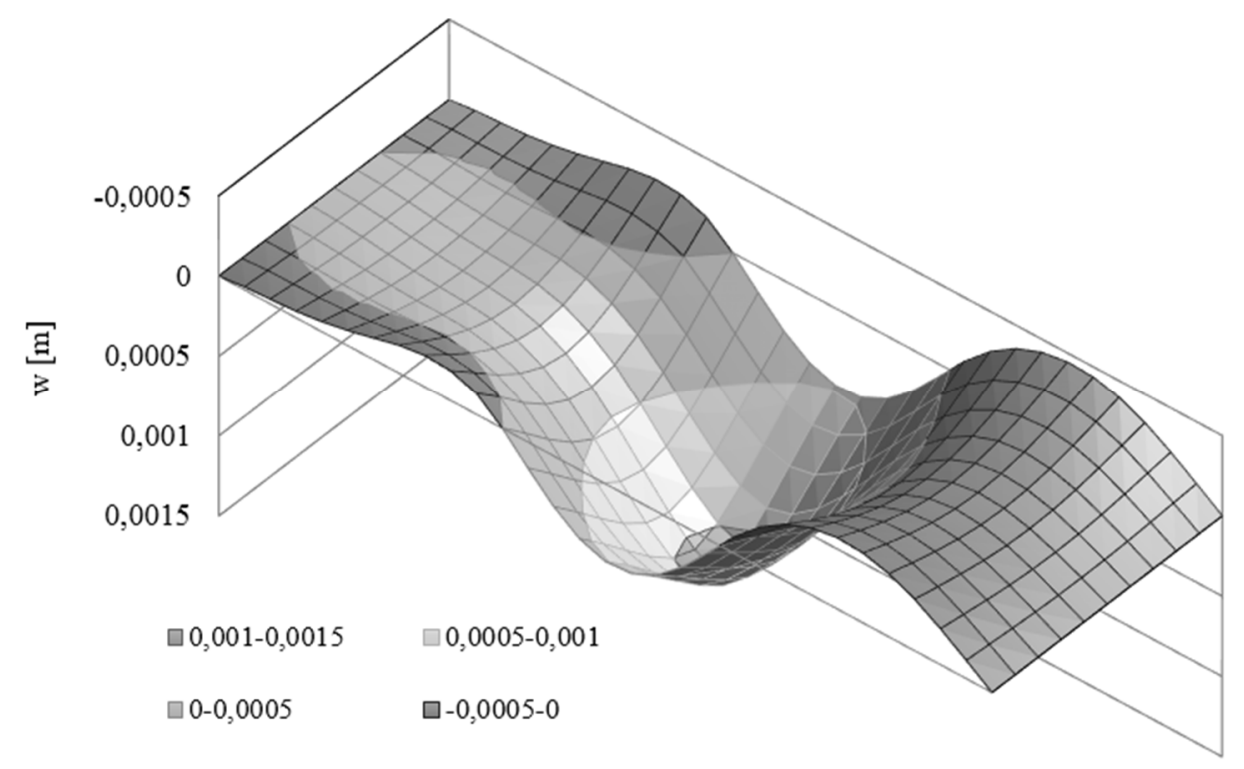

Rys. 8. Deformacja płyty wywołana ruchomą siłą skupioną $\mathrm{w}$ chwili $\mathrm{T}=0,5$

Fig. 8. Plate deformation resulting from the moving concentrated force at time $\mathrm{T}=0,5$

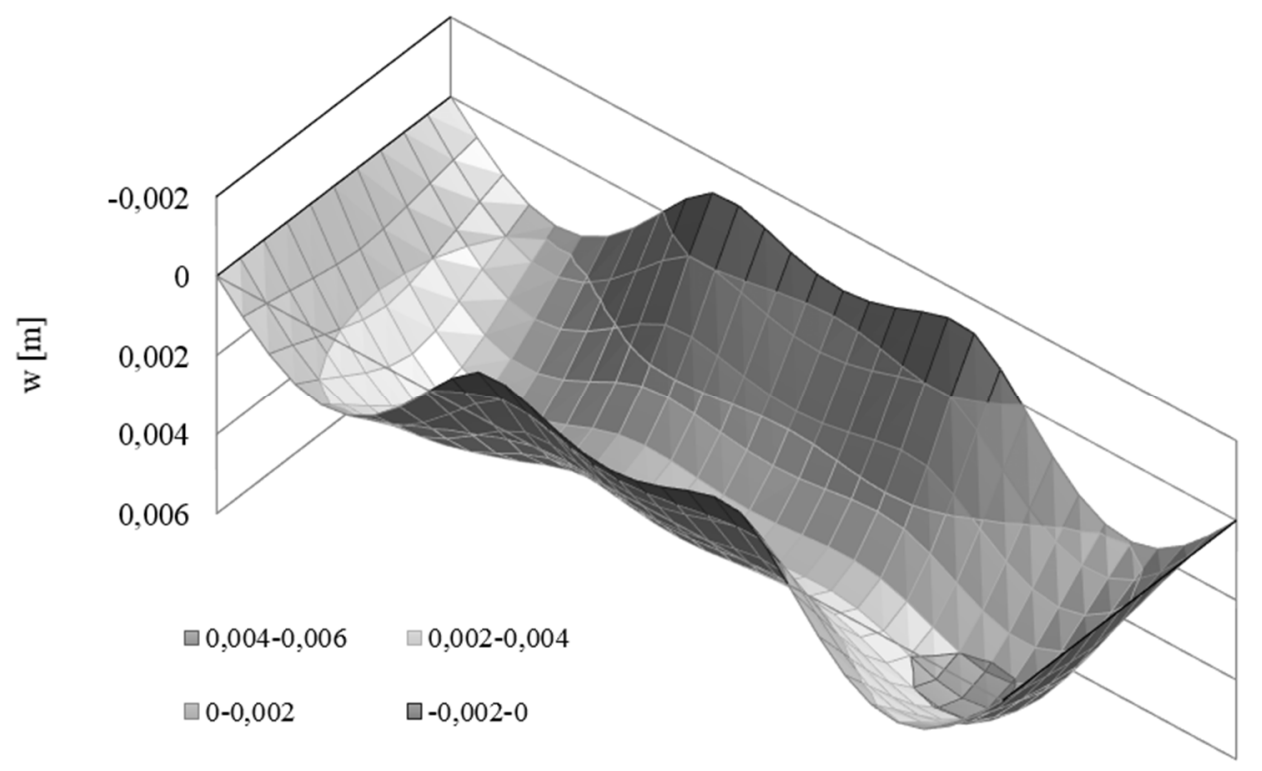

Rys. 9. Deformacja płyty wywołana ruchomym obciążeniem rozłożonym w chwili $\mathrm{T}=1,0$

Fig. 9. Plate deformation resulting from the moving distributed load at time $\mathrm{T}=1,0$ 


\section{Podsumowanie}

Metoda Różnic Skończonych może być z powodzeniem zastosowana w analizie drgań cienkich płyt mostowych poddanych działaniu różnego rodzaju obciążeń ruchomych. Zaletą metody jest jej prostota w budowaniu modelu dyskretnego oraz formułowaniu i modyfikowaniu macierzowego równania ruchu. Metodę tą można zastosować również, po wprowadzeniu odpowiednich zmian, w analizie drgań thumionych (konieczność określenia modelu tłumienia oraz budowy macierzy tłumienia), jak również w analizie drgań wywołanych obciążeniami inercyjnymi. Zastosowanie odpowiednich formuł opisanych m.in. w [8] pozwoli zastosować Metodę Różnic Skończonych przy bardziej skomplikowanych układach, takich jak płyty o nieregularnym kształcie, zmiennej sztywności giętnej czy też płyty spoczywające na podłożu sprężystym. Prezentowana metoda może znaleźć zastosowanie jako metoda weryfikacyjna dla rozwiązań analitycznych, a także innych metod numerycznych takich jak Metoda Elementów Skończonych.

\section{Literatura}

[1] Fryba L.: Vibration of Solids and Structures under Moving Loads, Telford, London 1999.

[2] Leissa A.W.: Vibrations of Plates, US Government Printing Office, Washington DC 1969.

[3] Szcześniak W.: Wybrane zagadnienia z dynamiki płyt, Oficyna Wydawnicza Politechniki Warszawskiej, Warszawa 2000.

[4] Timoshenko S.P.: Theory of plates and shells, Mc Graw-Hill, New York 1959.

[5] Zhu X.Q., Law S.S.: Dynamic behavior of orthotropic rectangular plates under moving loads, Journal of Engineering Mechanics, vol. 129, no. 1, 2003, pp. 79-87.

[6] Zakęś F., Śniady P.: Application of Volterra integral equations in dynamics of multispan continuous beams subjected to a moving load, Shock and Vibrations, vol. 2016.

[7] Zakęś F.: Vibrations of point-supported rectangular thin plate subjected to a moving force, Engineering Transactions, vol. 64, no. 4, 2016 pp. 409-415.

[8] Kączkowski Z.: Płyty - obliczenia statyczne, Wydawnictwo Arkady, Warszawa 1980.

[9] Newmark N.M.: A method of computation for structural dynamics, ASCE Journal of the Engineering Mechanics Division 1959; EM3: pp. 67-95.

\section{APPLICATION OF FINITE DIFFERENCE METHOD IN DYNAMICS OF THIN BRIDGE PLATES SUBJECTED TO MOVING LOADS}

\section{S u m m a r y}

This paper presents solution of problem of undamped vibrations of thin rectangular bridge plate subjected to a non-inertial load moving with constant velocity. In order to spatial discretiza- 
tion of the plate numerical procedures have been applied as well as formulas of Newmark method applied to discretize time of the load movement. Formulas required to build and solve matrix equation of motion have been given as well as formulas for load vectors corresponding with two cases of moving load namely the case of moving constant force and the case of moving distributed load. A numerical example of a bridge plate with 4 point supports subjected to 2 types of moving load has been presented in order to show the efficiency of the method.

Keywords: Finite Difference Method, moving load, thin plate, Newmark Method

Przestano do redakcji: $13.02 .2017 \mathrm{r}$.

Przyjęto do druku: 28.04.2017 r. 